\title{
THE COPPER CONTENT IN THE BLOOD PLASMA OF CHILDREN WITH DIFFERENT TYPES OF SHORT STATURE
}

D0l: $10.36740 /$ WLek202002111

\author{
Tamila V. Sorokman', Snezhana V. Sokolnyk', Oleksandra-Maria V. Popelyuk², Tetyana 0. Bezruk', \\ Olena V. Makarova ${ }^{4}$ \\ 'DEPARTMENT OF PEDIATRICS AND MEDICAL GENETICS, BUKOVINIAN STATE MEDICAL UNIVERSITY, CHERNIVTSI, UKRAINE \\ 2DEPARTMENT OF HUMAN ANATOMY MYKOLA TURKEVICH, BUKOVINIAN STATE MEDICAL UNIVERSITY, CHERNIVTSI, UKRAINE \\ ${ }^{3}$ DEPARTMENT OF INTERNAL MEDICINE MEDICINE, BUKOVINIAN STATE MEDICAL UNIVERSITY, CHERNIVTSI, UKRAINE \\ ${ }^{4}$ DEPARTMENT NURSING OF HIGHER NURSING EDUCATION, BUKOVINIAN STATE MEDICAL UNIVERSITY, CHERNIVTSI, UKRAINE
}

\begin{abstract}
The aim: to investigate the copper content in blood serum of children with different short stature types.

Materials and methods: In the first stage, a comprehensive survey of 258 school children aged 7-11 was carried out in Chernivtsi to assess the prevalence of short stature children of school-age. In the second stage, a comparative study of 42 children aged 3 to 15 years with different types of short stature was conducted. Research: anthropometry, determination of growth hormone, TSH, IGF-1, and copper level in blood plasma.

Results: The largest growth rate in children with somatotropic insufficiency, the syndrome of a biologically inactive growth hormone ranged from $4.1 \mathrm{~cm} / \mathrm{year}$ to $1.6 \mathrm{~cm} / \mathrm{year}$, the ones with a family constitutional low-growth - from $5.7 \mathrm{~cm} /$ year to $3.3 \mathrm{~cm} /$ year. In 57 cases, that makes $1 \%$ of children with short stature, the blood plasma level of copper made less and rated $0.89 \pm 0.04 \mu \mathrm{g} / \mathrm{ml}$, which is believed to be lower (py0,001) the average copper in children of the control group $-1.07 \pm 0.02 \mu \mathrm{g} / \mathrm{ml}$. Indices of copper in blood plasma in children with somatotropic insufficiency were the lowest and averaged $0.75 \pm 0.03 \mu \mathrm{g} / \mathrm{l}, \mathrm{p}<0.05$.

Conclusions: The lack of copper in the blood plasma is observed in most children with short stature, which indicates the need for appropriate correction.
\end{abstract}

KEY WORDS: children, short stature, copper level

Wiad Lek. 2020;73(2):266-271

\section{INTRODUCTION}

Scientific studies emphasize the important role of the micro elemental status of the human body in the functioning of all organs and systems [1]. Particular attention is paid to the study of the effect of essential micronutrients (EM) on human health, and children with growth retardation in particular [2]. The regular intake of food or water with microelements that are part of enzymes, vitamins, hormones and other biologically active substances, is necessary for human vital functions. Children, due to the growth processes activity, are particularly sensitive to dietary mineral deficiencies [3]. For a child's growing and developing body, some of the chemical elements are essential. Among them, copper deserves special attention. The literature data highlight the role of copper deficiency and characterize copper deficiency states, which lead to the violation of embryonic development $[4,5]$. Copper deficiency during pregnancy leads to death of a fetus, a high percentage of intrauterine anomalies of the internal organs (heart defects, anomalies of blood vessels), growth and fetal hemopoiesis disturbances. Despite the increased concentration of copper in the blood of pregnant women and active transplacental transport, the symptoms of its failure in newborns and infants occur quite often. It manifests as muscle hypotonia, impaired blood circulation, changes in bone tissue, hepatosplenomegaly, that is, that means systemic dysplasia of the connective tissue. The lack of copper is associated with a delay in psychomotor development in the postnatal period [6]. Low levels of zinc, copper, and iron are important risk factors for osteoporosis [7].

With the lack of copper in chondro- and osteoblasts, the activity of enzyme systems decreases and protein metabolism slows down, resulting in a retardation of bone tissue growth [8]. Metabolism of copper in the human body is presented in Figure 1.

\section{THE AIM}

Aim - to investigate the level of copper in the blood plasma of children with different types of short stature.

\section{MATERIALS AND METHODS}

It the first stage, a comprehensive survey of 258 school children aged 7-11 was carried out in Chernivtsi to assess the prevalence of short stature children of school-age. Graders were selected on an occasional basis. It the second stage, a comparative case-control study was conducted. We 


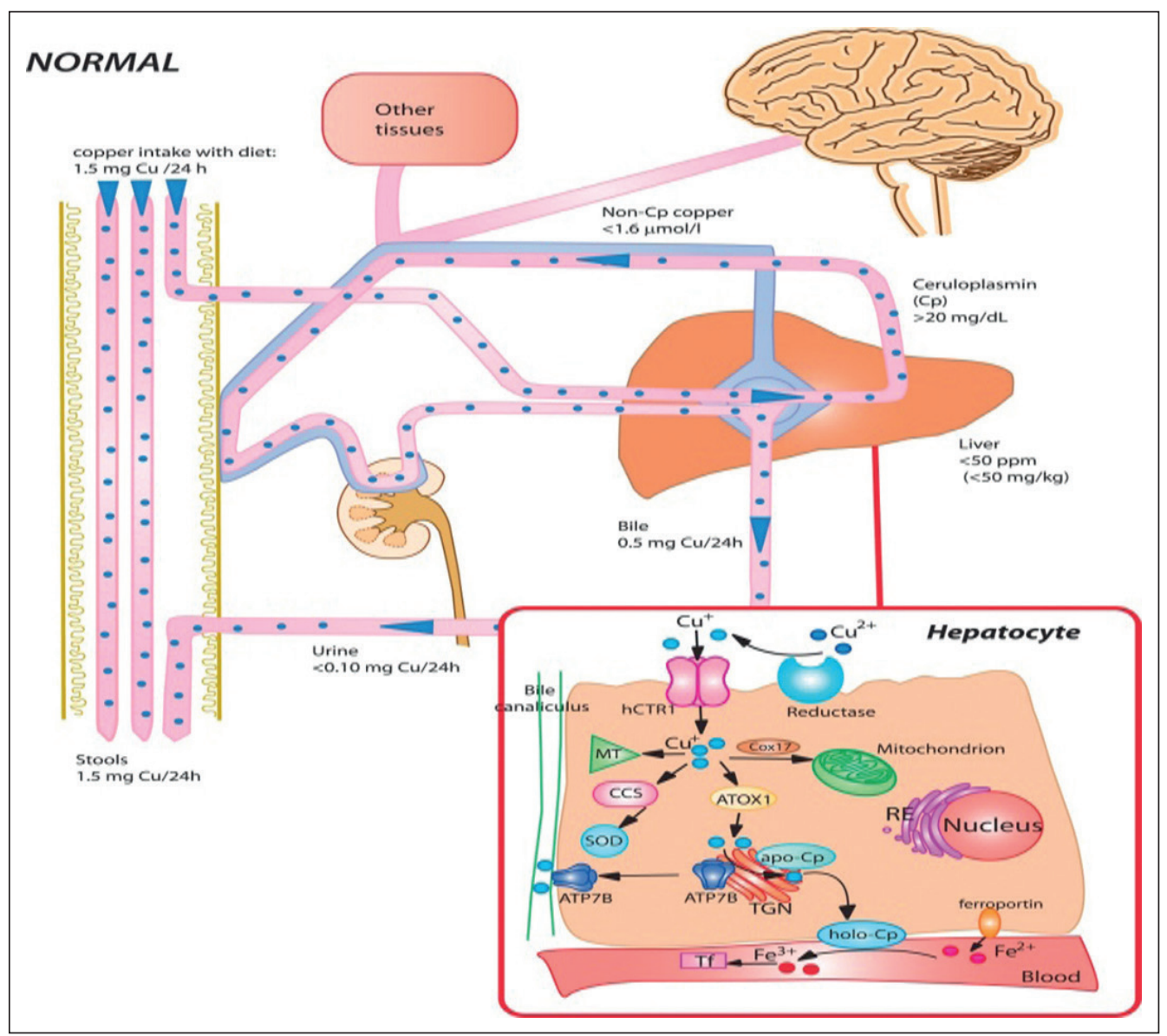

Fig. 1. The normal pathway for copper absorption.

Copper dietary intake in 24 hours is $1.5 \mathrm{mg} ; 0.5 \mathrm{mg}$ per day of this copper is absorbed from duodenum and transported to the liver through the portal system. In the liver, the copper is structurally incorporated into ceruloplasmin (Cp) by the copper pump ATP7B. Normal values of $(p$ are $>20 \mathrm{mg} / \mathrm{dL}$; the concentrations of non-C $p$ copper and urinary copper after an overnight fast are $<1.6 \mu \mathrm{mol} / \mathrm{L}$. Red box indicates the hepatocyte. A still unknown reductase protein reduces $\mathrm{Cu} 2+$ to $\mathrm{Cu}+$, which is then imported into the cell by human copper transporter 1 ( $\mathrm{hCTR} 1)$. Once in the cell, copper is carried by cytochrome Coxidase assembly homolog (COX17) to the mitochondria, by the copper chaperone for superoxide dismutase (CCS) to the superoxide dismutase (SOD) and by the antioxidant protein 1 homolog (ATOX1) to the ATP7B. In the trans-Golgi network (TGN), the ATP7B protein loads copper into nascent apo-Cp to form active holo-Cp. [9].

Table I. Physical development of the examined children

\begin{tabular}{|c|c|c|c|c|c|c|}
\hline \multirow{2}{*}{ Centiles } & \multicolumn{3}{|c|}{ Absolute number of children } & \multicolumn{3}{|c|}{ Relative number of children } \\
\hline & Girls & Boys & Total & Girls & Boys & Total \\
\hline Less than 3 & 4 & 3 & 7 & 1,5 & 1,2 & 2,7 \\
\hline $3-10$ & 8 & 16 & 24 & 3,1 & 6,2 & 9,3 \\
\hline $10-25$ & 25 & 18 & 43 & 9,7 & 7,0 & 16,7 \\
\hline More 25 & 77 & 107 & 184 & 29,9 & 41,4 & 71,3 \\
\hline TOTAL & 114 & 144 & 258 & 44,2 & 55,8 & 100 \\
\hline
\end{tabular}

Table II. Distribution of children who participated in the study

\begin{tabular}{ccc}
\hline Nosology & Number of patients (boys / girls) & \% \\
\hline Somatotropic insufficiency is complete & $10(8 / 2)$ & 23,8 \\
\hline Somatotropic insufficiency is partial & $12(8 / 4)$ & 28,5 \\
\hline Inactive hormone growth syndrome & $4(3 / 1)$ & 9,5 \\
\hline Family-constitutional short stature & $14(8 / 6)$ & 33,3 \\
\hline Genetically determined short stature & $2(1 / 1)$ & 4,7 \\
\hline TOTAL & 42 & 100,0 \\
\hline
\end{tabular}




\section{SDS}

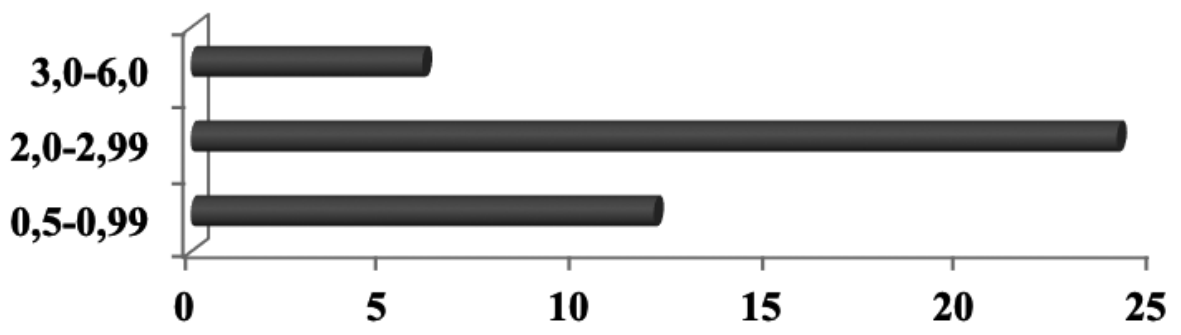

Fig.2. Distribution of the examined children by the standard deviation score (SDS).

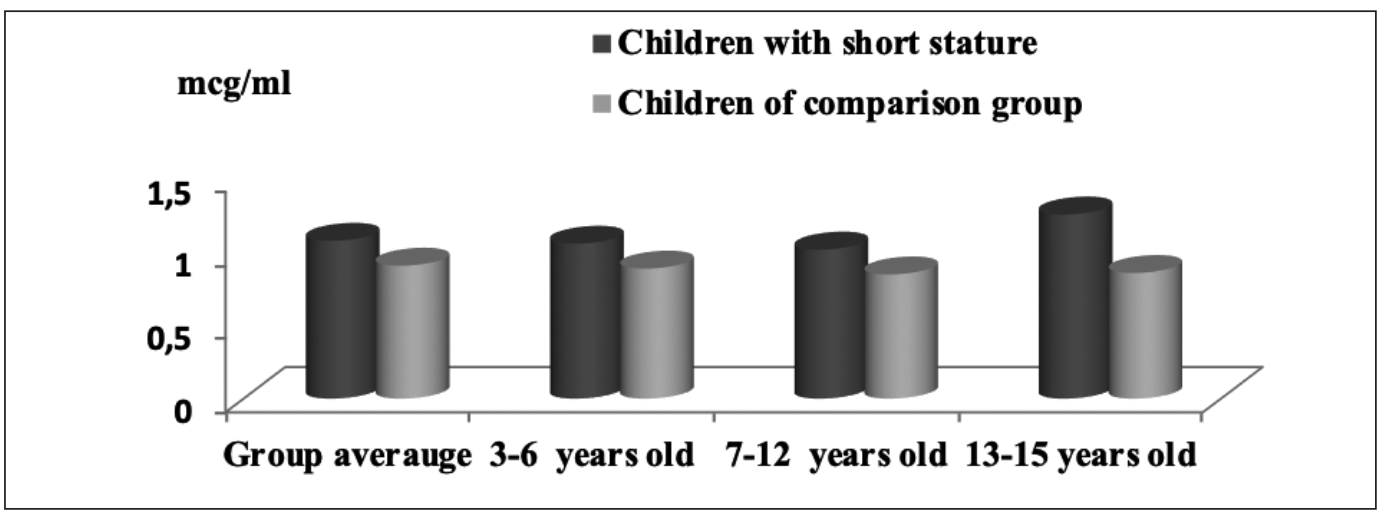

Fig. 3. Levels of copper in plasma of blood of examined children, $(p<0,001)$.

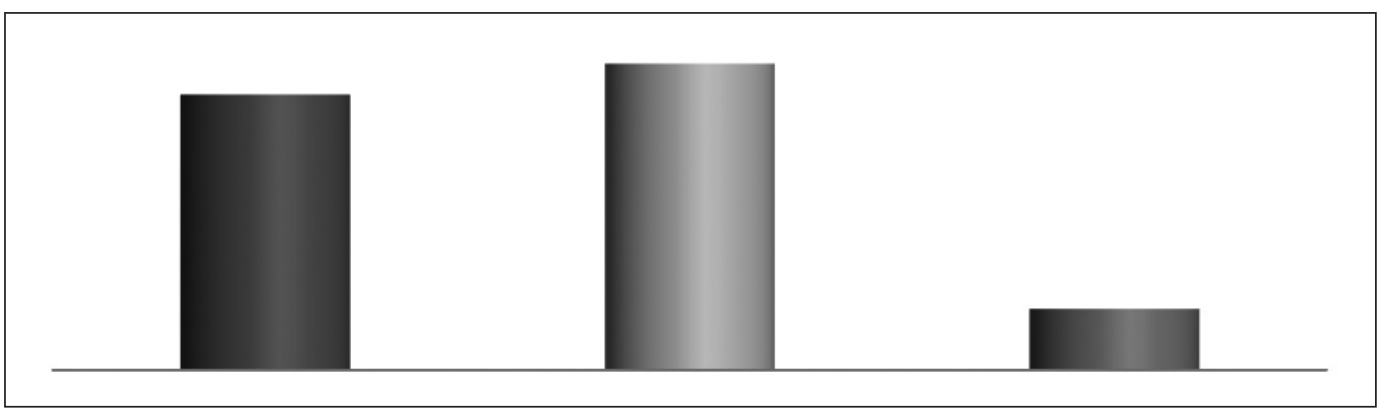

Fig.4. Distribution of children with short stature by the level of copper in blood plasma.

examined 42 children being under supervision in the children's endocrinology department of the Chernivtsi Oblast Children's Hospital during 2011-2018, aged 3 to 15 years (average age of $8.96 \pm 0.19$ ). Among them 28 boys (66.7\%) and 14 girls (33.3\%) with different types of short stature. Criteria for inclusion in the research: growth retardation, age from 3 to 15 years, residence on the territory of Chernivtsi region. Exclusion criteria: the presence of acute infectious disease, chronic somatic pathology, malabsorption syndrome, metabolic diseases, genetic and mental illnesses, residence outside the Chernivtsi region, absence of parental informed consent for examination. The control group consisted of 44 children aged 3-15 years, with an average age of $9.16 \pm 0.45$ years, boys -24 (54.5\%), girls -20 (45.4\%). These patients had no growth retardation, normal sexual development, and absence of somatic, genetic and endocrine pathology. Before the survey, patients and their parents gave informed consent to take part in the study and use the data obtained. All children were clinically examined, that included anthropometry (measurements of height using the "System Dr. Keller]" stadiometer, body mass measurements using the SECA electronic scales, find the standard deviation score (SDS) for growth and body weight using percentile curves, speed growth rate (SR), SDS growth rate, bone age (BA), bone age retardation, ossification coefficient (CO), body mass index (BMI)). Normally, the gap was minus 1 SDS plus 1 SDS $(\mathrm{M} \pm 1 \mathrm{SDS})$. Delay in physical development was diagnosed if the gap ranged from minus 1 to minus 2 SD; subnanizm - from minus 2 to minus 3 SD; nanism - from minus 3 SD and more. The atlas of W. W. Greulich, S. P. Pyle (1993) was used to determine the bone age. To detect the degree of BA from the passport age retar- 
Table III. Indices of height, body weight, BMI, bone age in patients with short stature, $(\mathrm{M} \pm \mathrm{m})$

\begin{tabular}{cccc}
\hline Index & $\begin{array}{c}\text { Children with } \\
\text { somatotropic insufficiency }\end{array}$ & $\begin{array}{c}\text { Children with a family- } \\
\text { constitutional short stature }\end{array}$ & $\begin{array}{c}\text { Children of the control } \\
\text { group }\end{array}$ \\
\hline Growth, $\mathrm{cm}$ & $111,89 \pm 1,15$ & $123,98 \pm 1,09$ & $134,3 \pm 1,71^{*}$ \\
\hline BMl, $\mathrm{kg} / \mathrm{m} 2$ & $17,03 \pm 0,21$ & $19,91 \pm 0,28$ & $22,18 \pm 0,57^{*}$ \\
\hline BA, years & $6,23 \pm 0,21$ & $9,19 \pm 0,32$ & $9,8 \pm 0,3^{*}$ \\
\hline BA retardation, years & $2,39 \pm 0,06$ & $1,74 \pm 0,15$ & - \\
\hline GR, $\mathrm{cm}$ & $3,12 \pm 0,04$ & $4,59 \pm 0,19$ & - \\
\hline SDS & $-2,91 \pm 0,08$ & $-2,13 \pm 0,07$ & - \\
\hline
\end{tabular}

Note. ${ }^{*}$ - $p<0,05$, the probability of changes in the indices compared to control group (BMI - body mass index, BA- bone age, GR - growth rate, SDS - standard deviation score).

Table IV. Indicators of GH and IFR-1 in children

\begin{tabular}{|c|c|c|c|c|c|c|c|c|c|c|c|c|}
\hline \multirow{3}{*}{ Index } & \multicolumn{12}{|c|}{ Age (years) } \\
\hline & \multicolumn{3}{|c|}{$3-6$} & \multicolumn{3}{|c|}{$7-12$} & \multicolumn{3}{|c|}{$13-15$} & \multirow{2}{*}{\multicolumn{3}{|c|}{ Control Group }} \\
\hline & 1 & 2 & 3 & 1 & 2 & 3 & 1 & 2 & 3 & & & \\
\hline \multirow{2}{*}{$\mathrm{GH}, \mathrm{ng} / \mathrm{ml}$} & $2,1 \pm$ & $11,9 \pm$ & $18,1 \pm$ & $2,0 \pm$ & $12,5 \pm$ & $16,6 \pm$ & $2,1 \pm$ & $13,1 \pm$ & $18,4 \pm$ & $2,4 \pm$ & $14,9 \pm$ & $21,2 \pm$ \\
\hline & 0,1 & 0,4 & 1,3 & 0,1 & 1,4 & 1,1 & 0,1 & 0,1 & 0,5 & $0,1^{*}$ & $1,2^{*}$ & $1,0^{*}$ \\
\hline IGF-1, ng / ml & \multicolumn{3}{|c|}{$70,4 \pm 8,1^{*}$} & \multicolumn{3}{|c|}{$139,7 \pm 15,1^{*}$} & \multicolumn{3}{|c|}{$198,2 \pm 18,7^{*}$} & \multicolumn{3}{|c|}{$231,4 \pm 11,5$} \\
\hline
\end{tabular}

Note. 1 - basic; 2 - night spontaneous peak; 3 - Clonidine test. ${ }^{*}-p<0,05$, the probability of changes in the indices compared to the control group (IGF-1 - insulin-like growth factor 1, GH - growth hormone).

dation, $\mathrm{CO}$ was determined - the ratio of the $\mathrm{X}$-ray age to the passport. All children underwent ultrasound examination of thyroid glands and thyroid hormones levels were measured.

The growth hormone (GH) level in blood plasma was determined by the immune-chemiluminescence method on IMMULITE 2000XPi, Siemens Healthcare Diagnostics Inc, USA, using the standard kit (basal level, somatotropic hormone release peak during a clonidine assay, and 2 hours after nocturnal release 2 hours after falling asleep). Levels of stimulated secretion of GH in standard samples $10 \mathrm{ng} / \mathrm{ml}$ and higher were taken as the norm. In healthy children, the release of GH after the test increased at least 5 times in comparison with the background indices. The content of IGF-1 was measured in blood in the morning using a solid phase sandwich enzyme-linked immunosorbent method with a set of reagents "DRG" (Germany).

The content of zinc in blood plasma was determined using an X-ray fluorescence spectrometer «ElvaX-med» (Ukraine) based on the measurement of the chemical elements in blood plasma content method (MVB 081 / 12-0468-07). To detect copper in blood plasma not less than $1.0 \mathrm{ml}$ of venous blood was used. The sample was dried in a drying cabinet.

The results of the study are statistically processed using the packages of computer programs "STATISTICA" for Windows 8.0.0. (SPSS I.N.C.; 1989-1997), STATISTICS V.6.0 (Statsoft Inc., 1984-1996). The likelihood of the difference was taken into account by the size of the probability $(\mathrm{p}<0,05)$.

The research is based on the main provisions of the ICH GCR and the Helsinki Declaration of the World Medical Association for Biomedical Research, involving human subjects (World Medical Association Declaration Helsinki 1964, 2000, 2008), the Council of Europe Convention on Human Rights and Biomedicine (2007.)

\section{RESULTS AND DISCUSSION}

Data on anthropometric indices of schoolchildren are given in Table I. In the population of schoolchildren, we found $2.7 \%$ short stature children, and $26 \%$ with growth rates lower than average. In calculating the growth SDS, 30 children had slight growth retardation (-1 -2 SD), one child had subnanizm $(-2.2 \mathrm{SD})$.

A large number of children with short stature dictates the need for the active introduction of preventive measures and the accentuation of pediatricians' attention to assessing the dynamics of anthropometric indices and timing the initiation of the diagnostic search. The distribution of children in inpatient care and their participation in the second stage of the study is presented in Table II and Figure 2.

During the examination of children, the attention was paid to body proportions, features of the face, the presence of dysembryogenesis stigmas, condition of hair, skin, voice timbre, body weight, genital organs development, and psychomotor status. The diffuse goiter was found in 10 cases (23.8\%), autoimmune thyroiditis - in 2 cases (4.7\%), primary hypothyroidism - in 1 case (2.3\%).

The main complaint of patients was the growth retardation $1-3 \mathrm{~cm}$ per year over the past few years. In $5(11.9 \%)$ children growth retardation was observed from birth. The largest growth rate in short stature children, depending on the retardation cause was the following: in case of somatotropic insufficiency, the syndrome of a biologically inactive 
growth hormone - from $4.1 \mathrm{~cm} /$ year to $1.6 \mathrm{~cm} /$ year (on average $3.4 \pm 0.9 \mathrm{~cm} /$ year), a family-constitutional short stature - from $5.7 \mathrm{~cm} /$ year to $3.3 \mathrm{~cm} /$ year (an average of $4.5 \pm 1.0 \mathrm{~cm} /$ year). According to the clinical examination results, a different degree of retardation - from physical development delay (minus 1.05 SDS) to nanism (minus 3-6.0 SDS) was detected with the proportional body structure and lack of dysembriogenesis stigmas background. The observed body mass deficiency was proportional to growth retardation. BMI in the majority of cases was within the mean values and reached $11.5-24.9 \mathrm{~kg} / \mathrm{m} 2$, only in children (9.5\%) it exceeded $25 \mathrm{~kg} / \mathrm{m} 2$. In the study of bone age, the retardation of the skeleton maturation for 5,5 $\pm 0,4$ years is established. In all children with short stature, significant growth retardation in all age groups was detected to be greater than minus $2.5 \mathrm{SDS}$ and a probable decrease in mean growth rates compared to the control group ( $<<0,01$, Table III). Children of elementary-school age have registered a significantly lower bone age (BA) in boys than girls $(p<0.05)$. The average retardation in the BA of this group's children was more substantial in boys than in girls $(p<0.05)$.

Indices of GF and IGF-1 in short stature children and ones in comparison groups are presented in Table IV.

According to the results of the study, it was detected that in more than half of children with short stature $(57,1 \%)$ the level of copper in blood plasma is decreased. The average level of copper in the blood plasma of children with short stature was $0.89 \pm 0.04 \mu \mathrm{g} / \mathrm{ml}$, which is lower $(\mathrm{p}<0.001)$ compared to the control group $-1.07 \pm 0.02 \mu \mathrm{g} / \mathrm{ml}$ (Fig. $3)$. In all age groups, there was a significant decrease in copper in blood plasma compared with the corresponding age group of the control group.

Zinc level was significantly low in $20(47.6 \%)$ cases, in $4(9.5 \%)$ cases it was very low and in the remaining 18 (42.8\%) it had the lowest boundary values (Fig. 4). At the same time, children in the comparison group did not show a decrease in copper levels, however, 20 children (45.4\%) had a lower limit of the norm. Indicators of copper in blood plasma in children with somatotropic insufficiency were the lowest and averaged $0.75 \pm 0.03 \mu \mathrm{g} / \mathrm{l}, \mathrm{p}<0.05$.

The results of the copper levels analysis, depending on the nosological group, revealed its probable decrease in the blood plasma in children with somatotropic insufficiency and family-constitutional malnutrition, but no gender differences were found. The following parameters, such as the activity of the superoxide dismutase enzyme, serum levels of ceruloplasmin, serum copper levels, daily excretion of copper and urine, and the concentration of this trace element in the hair, can be used in assessing the trace elemental status of the body with respect to copper. The recent studies suggest the need to organize research on the detection of deficiencies of essential micronutrients in children, correction of detected short stature, in particular, food [10] and expediency of drugs containing essential elements (iron, iodine, copper, manganese, zinc, cobalt , molybdenum, selenium, chromium, fluorine) inclusion, to the schemes of complex treatment of many endocrine diseases of the child and adolescence (eg. obesity [11]). WHO proposed standards for the use of essential micronutrients [12]. Studies [13] conducted in Poland have shown that more than 20,000 children in Poland have problems with growth impairment. The results showed no statistically significant differences between the copper concentration and age, body weight and height, but demonstrated statistically significant differences between the content of essential metals in the body fluids of short stature children and healthy children. The authors suggest that changes in the content of metals and their interaction can play an important role in the pathogenesis of short stature. It is advisable to recommend to pregnant women a complete, balanced diet enriched with the necessary micronutrients, since premature babies have a marked deficiency of trace elements, especially in case of intrauterine growth retardation [14].

\section{CONCLUSIONS}

The lack of copper in the blood plasma is observed in most children with short stature, which indicates the need for appropriate correction.

\section{RESTRICTION OF RESEARCH}

Blood collection in most patients was conducted in the spring-summer period, which may not adequately show the content of copper in other seasons.

\section{REFERENCES}

1. Masumoto K. Trace elements deficiency in children receiving nutritional management. Nihon Rinsho. 2016; 74(7):1214-9.

2. Berkovitch M, Heyman E, Afriat R, Matz-Khromchenko I, Avgil $M$, Greenberg R, Zimmerman DR [et al]. Copper and zinc blood levels among children with nonorganic failure to thrive. Clin Nutr. 2003; 22(2):183-6.

3. Cao J, Gao Z, Yan J, Li M, Su J, Xu J, Yan CH. Evaluation of Trace Elements and Their Relationship with Growth and Development of Young Children. Biol Trace Elem Res. 2016; 171(2):270-274. doi: 10.1007/ s12011-015-0537-7.

4. Al-Saleh E, Nandakumaran M, Al-Shammari M, Makhseed M, Sadan T, Harouny A. Maternal-fetal status of copper, iron, molybdenum, selenium and zinc in insulin-dependent diabetic pregnancies. Arch Gynecol Obstet. 2005; 271:212-7.

5. Özden TA, Gökçay G, Cantez MS, Durmaz Ö, İssever H, Ömer B, Saner G. Copper, zinc and iron levels in infants and their mothers during the first year of life: a prospective study. BMC Pediatr. 2015; 15: 157.

6. Marquardt ML, Done SL, Sandrock M, Berdon WE, Feldman KW. Copper deficiency presenting as metabolic bone disease in extremely low birth weight, short-gut infants. Pediatrics. 2012;130:e695-e698. doi: 10.1542/peds.2011-1295.

7. Suliburska J, Kocyłowski R, Komorowicz I, Grzesiak M, Bogdański P, Barałkiewicz D. Concentrations of Mineral in Amniotic Fluid and Their Relations to Selected Maternal and Fetal Parameters. Biol Trace Elem Res. 2016; 172(1): 37-45. doi: 10.1007/s12011-015-0557-3.

8. Tabrizi FM, Pakdel FG. Serum level of some minerals during three trimesters of pregnancy in iranian women and their newborns: a longitudinal study. Indian J Clin Biochem. 2014; 29(2):174-180. doi: 10.1007/s12291-013-0336-X. 
9. Tabrizi FM, Pakdel FG. Serum Level of Some Minerals during Three Trimesters of Pregnancy in Iranian Women and Their Newborns: A Longitudinal Study. Indian J Clin Biochem. 2014; 29(2): 174-180. doi: 10.1007/s12291-013-0336-X.

10. Keen CL, Uriu-Hare JY, Hawk SN, Jankowski MA, Daston GP, Kwik-Uribe $\mathrm{CL}$ et al. Effect of copper deficiency on prenatal development and pregnancy outcome. Am J Clin Nutr. 1998; 67:1003S-11S. doi: 10.1093/ ajcn/67.5.1003S.

11. Benes B, Sladka J, Spevackova V, Smid J. Determination of normal concentration levels of $\mathrm{Cd}, \mathrm{Cr}, \mathrm{Cu}, \mathrm{Hg}, \mathrm{Pb}, \mathrm{Se}$ and $\mathrm{Zn}$ in hair of the child population in the Czech Republic. Centr. Eur. J. Public Health. 2003; 11(4):184-186.

12. Zheng J, Mao X, Ling J, He Q, Quan J. Low serum levels of zinc, copper, and iron as a risk factor for osteoporosis: a meta- analysis. Biol Trace Elem Res. 2014; 160:15-23. doi: 10.1007/s12011-014-0031-7.

13. Rodionova LV. Physiological role of macro and microelements. Bulletin of SSC of RAMS. 2005; 6 (44):196-199.

14. Rosanna Squitti, Mariacristina Siottoc, Renato Polimanti. Low-copper diet as a preventive strategy for Alzheimer's disease Neurobiology of Aging. 2014; 35(2):S40-S50. https://doi.org/10.1016/j. neurobiolaging.2014.02.031

15. Klevay LM. Copper and public health: dietary intakes vs. clinical data. J Trace Elem Med Biol. 2014 Jul;28(3):354. doi: 10.1016/j. jtemb.2014.03.002.

16. Błażewicz A, Klatka M, Astel A, Partyka M, Kocjan R. Differences in trace metal concentrations ( $\mathrm{Co}, \mathrm{Cu}, \mathrm{Fe}, \mathrm{Mn}, \mathrm{Zn}, \mathrm{Cd}$, And $\mathrm{Ni})$ in whole blood, plasma, and urine of obese and nonobese children. Biol Trace Elem Res. 2013 Nov; 155(2):190-200. doi: 10.1007/s12011-013-9783-8. Epub 2013 Aug 22.

17. IPCS. Copper. FAO/WHO, Klevay. 1999, p 224.

18. Klatka M, Błażewicz A, Partyka M, Kołłątaj W, Zienkiewicz E, Kocjan R. Concentration of Selected Metals in Whole Blood, Plasma, and Urine in Short Stature and Healthy Children. Biol Trace Elem Res. 2015 Aug; 166(2):142-8. doi: 10. 1007/s12011-015-0262-2.

19. Lewicka I, Kocyłowski R, Grzesiak M, Gaj Z, Oszukowski P, Suliburska J. Selected trace elements concentrations in pregnancy and their possible role - literature review. Ginekol Pol. 2017;88(9):509-514. doi: 10.5603/ GP.a2017.0093.

20. Tabrizi FM, Pakdel FG. Serum Level of Some Minerals during Three Trimesters of Pregnancy in Iranian Women and Their Newborns: A Longitudinal Study. Indian J Clin Biochem. 2014; 29(2): 174-180. doi: 10.1007/s12291-013-0336-X.
21. Jariwala M, Suvarna S, Kiran Kumar G, Amin A, Udas AC. Study of the concentration of trace elements fe, $\mathrm{zn}, \mathrm{Cu}$, se and their correlation in maternal serum, cord serum and colostrums. Indian J Clin Biochem. 2014; 29(2): 181-188. doi: 10.1007/s12291-013-0338-8.

22. Ugwuja El, Nnabu RC, Ezeonu P0, Uro-Chukwu H. The effect of parity on maternal body mass index, plasma mineral element status and new-born anthropometrics. Afr Health Sci. 2015 Sep; 15(3):986-92. doi: 10.4314/ahs.v15i3.37.

23. Ugwuja El, Akubugwo El, Ibiam UA, Obidoa 0. Impact of Maternal Copper and Zinc Status on Pregnancy Outcomes in a Population of Pregnant Nigerians. Pak J Nutr. 2010; 9:678-682.

24. Ugwuja El, Akubugwo El, Ibiam UA, et al. Plasma Copper and Zinc among Pregnant Women in Abakaliki, Southeastern Nigeria. The Internet Journal of Nutrition and Wellness. 2010; 10:1.

\section{ORCID and contributionship:}

Tamila V. Sorokman - 0000-0001-7615-3466 A,F

Snezhana V. Sokolnyk - 0000-0002-9399-4010 ${ }^{B}$

Olena V. Makarova - 0000-0003-3348-2440 ${ }^{E}$

Oleksandra-Maria V. Popelyuk - 0000-0002-9829-8647 D

Tetyana O. Bezruk - 0000-0003-3364-7233 ${ }^{\mathrm{C}}$

\section{Conflicts of interest:}

Authors declare no conflict of interest.

\section{CORRESPONDING AUTHOR Tamila V. Sorokman \\ Department of Pediatrics and Medical Genetics, Bukovinian State Medical University, \\ Chernivtsi, Ukraine \\ e-mail: t.sorokman@gmail.com}

Received: 25.04 .2019

Accepted: 03.12.2019

A - Work concept and design, B - Data collection and analysis, C - Responsibility for statistical analysis, D-Writing the article, $\mathbf{E}$-Critical review, $\mathbf{F}$ - Final approval of the article 